\title{
MOLECULAR DOCKING STUDIES OF ISOLATED FLAVONOIDS COMPOUNDS FROM AMARANTHUS TRISTIS LINN. AS ALPHA-AMYLASE AND ALPHA-GLUCOSIDASE ACTIVATORS
}

\author{
SUNDAR RAJAN T ${ }^{1}$, VIJEY AANANDHI $\mathbf{M}^{2 *}$ \\ ${ }^{1}$ Department of Pharmaceutical Chemistry and Analysis, School of Pharmaceutical Sciences, Vels Institute of Science, Technology and \\ Advanced Studies, Chennai, Tamil Nadu, India. ${ }^{2}$ Department of Pharmaceutical Chemistry, School of Pharmaceutical Sciences, Vels \\ Institute of Science, Technology and Advanced Studies, Chennai, Tamil Nadu, India. Email: hodpchemistry@velsuniv.ac.in
}

Received: 10 October 2018, Revised and Accepted: 11 December 2018

ABSTRACT

Aim: Aim of this work on in silico approach to used to access the use of flavonids compounds of nutritionally enriched plant Amaranthus tristis Linn.

Methods: Bioflavonoids of rutin isolated from A. tristis Linn. and active agents receptor such as alpha-amylase (1SMD) and alpha-glucosidase (3wy1) activators. Three-dimensional structure of receptors was obtained from protein data bank database and biocomponents such as isoflavones and flavonones of $A$. tristis were downloaded from database like USDA. Docking studies of insulin receptor with $A$. tristis biocomponents for isoflavones and flavonones were performed using AutoDock - 1.5.6 software.

Results: Compounds from A. tristis Linn. showed better binding features with the alpha-amylase and alpha-glycosidase. Thus, these compounds can be effectively used as drugs for treating diabetes which is predicted on the basis of docking scores.

Conclusion: The insights gained in this work can be further used in experimental studies for designing antidiabetic drugs with novel targets and mode of action.

Keywords: Diabetes, Alpha-amylase, Alpha-glucosidase, Flavonones, Amaranthus tristis Linn. docking, Rutin.

(C) 2018 The Authors. Published by Innovare Academic Sciences Pvt Ltd. This is an open access article under the CC BY license (http://creativecommons. org/licenses/by/4. 0/) DOI: http://dx.doi.org/10.22159/ajpcr.2018.v11s4.31676

\section{INTRODUCTION}

Diabetes is a metabolic issue in which glucose level rises due to the absence of insulin. It is characterized by insulin resistance and relative insufficiency of insulin. It is one of the significant ailments around the globe which can result in diabetic retinopathy, neuropathy, and numerous different conditions that may prompt passing. Insulin receptor has a place with the class of tyrosine kinase. The official of insulin to receptor causes conformational changes in the receptor prompting the actuation of beta subunit of tyrosine kinase [1]. Insulin is in charge of phosphorylation of insulin receptor that prompts glucose take-up by the cells. Most cells of the body have insulin receptors which tie the insulin and start a course of occasions that intervene the retention of glucose from the blood into the cell. Flavonoids are outstanding for their multidirectional natural exercises including hostile to diabetic viability. The flavonoids are the biggest class of polyphenols with a typical structure of diphenylpropanes [2].

Amaranthus tristis Linn. family Amaranthaceae, have long history of leafy vegetables are essential sustenance in traditional food due to its nutritional benefits, $A$. tristis Linn. have been used as food as well as for combating various disorders traditionally [3]. Both the plants have been reported to possess unique bioactive compounds that contribute to the pharmacological activities of that plant. A. tristis Linn. is a common edible plant that contains amarantin, isoamarantin, betaine, amino acids, and sterols. It has great medicinal value, as it is used as an astringent in dysentery, diarrhea, and hemorrhagic colitis and also used in cough and bronchitis [4].

A. tristis Linn. and used in indigenous system of medicine since many years' local people used as food substances limited activities reported, but the ethnobotanical report reveals that $A$. tristis Linn. have antioxidant potential, this plant is now gaining importance for future research and development [5].

\section{METHODS}

\section{Collection of medicinal plant}

The plant of $A$. tristis Linn. collected in the place of Yercaud Hills, Tamil Nadu, India. In the long stretch of September 2017, the plant material was taxonomically recognized, affirmed, and authenticated by $A$. tristis Linn. by Dr. K. Madavacheety, Venkateswara University, Tirupati, and the voucher specimen was retained in our laboratory for future reference.

\section{Preparation of plant extract}

The dried leaves were made into coarse powder with the help of dry mechanical grinder and passed through the sieve number 60 . The powdered leaves extracted using soxhlation method. The powder was defatted with petroleum ether $\left(40-60^{\circ} \mathrm{C}\right)$ and extracted with ethanol. Extracts subjected to rotary evaporator to remove solvents. This extract used to perform preliminary phytochemical marker analysis was done using the standard procedure [6].

\section{Isolation of compound}

The compound obtained from various fractions of chloroform: ethanol solvent system in column chromatography with gradient elution technique. Isolated compound was confirmed by spectral studies.

\section{Software's required}

Python 2.7 language downloaded from www.python.com, a data storage using Cygwin c:program and Python 2.5 was concurrently downloaded with www.cygwin.com, molecular graphics laboratory (MGL) equipment, and AutoDock 1.5.6 [7].

\section{Docking structures preparation}

Ligands have been drawn and geometrically optimized using software like ChemSketch 10.0. MGLTools 1.5.1 was used each ligand to put together and receptors for the docking. All the allowed torsions within the ligands had been set as flexible. Protein data bank (PDB) structure 


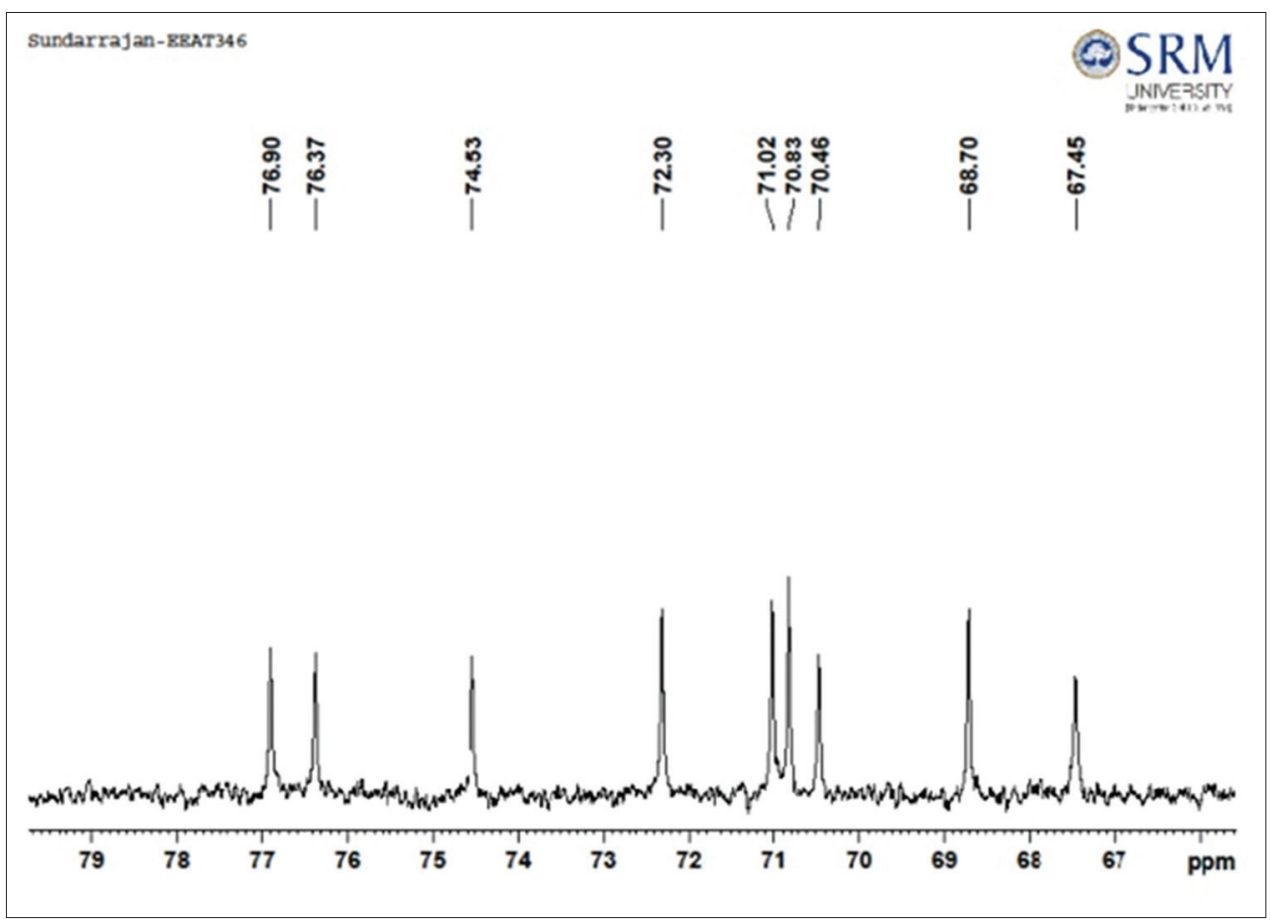

Fig. 1: ${ }^{13} \mathrm{C}$ nuclear magnetic resonance spectra of isolated compound

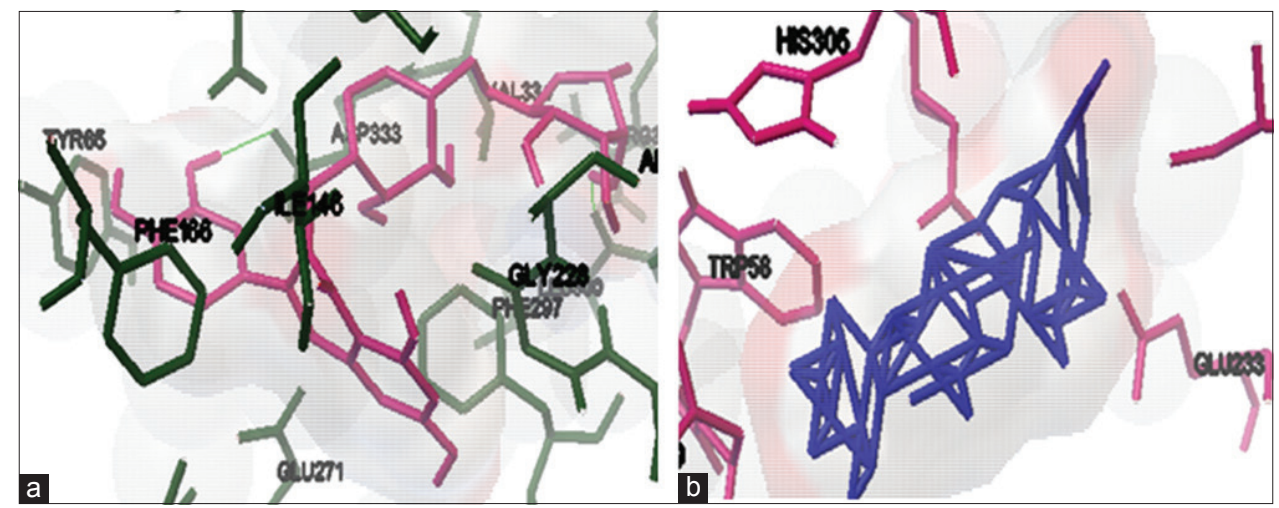

Fig. 2: ( $a$ and b) Docked pose of alpha-amylase enzyme (1MSD) with rutin and acarbose

of enzyme such as alpha-amylase (1SMD) and alpha-glucosidase (3wy1) enzymes became used as receptors. All the hetero atoms with water molecules and bound ligands in PDB crystal structures were removed from the receptors. After adding polar hydrogen and charges, the receptor was set as rigid with no flexible bonds [8].

\section{Docking studies}

Molecular docking research was performed for the chosen compounds with alpha-amylase and alpha-glucosidase enzyme through an automated docking device, AutoDock 1.5 .6 which matches by way of by Lamarckian Genetic Algorithm [9]. The correct interaction of bioactive substance or molecules with targets is essential for drug design and development process. AutoDock combines two techniques such as rapid grid-based energy evaluation and efficient search of torsional freedom [10].

\section{Discovery studio visualizer}

In this technique used by Accelrys with free and molecular modeling environment for both micromolecules and macromolecules programs. It generates the second receptor-ligand interplay plots and analyzes the ligand binding patterns between a protein and its bound ligand [11].

\section{RESULTS AND DISCUSSION}

The preliminary phytochemical tests for the ethanol extract of $A$. tristis Linn. leaves revealed the presence of carbohydrates, alkaloids, flavonoids, tannins, steroidal glycosides, and phenols. Isolated compound obtained from various fractions of chloroform:ethanol (9:1) solvent system in column and the presence of bioactive compounds was confirmed by thin-layer chromatography, melting point, and fraction showed positive test for flavonoids. The structure of isolated compound confirmed with the help of spectral studies such as Fourier transform infrared, ${ }^{1} \mathrm{H},{ }^{13} \mathrm{C}$ nuclear magnetic resonance, and gas chromatographymass spectrometry. Interpretation data reveals that positive with rutin (Fig. 1).

\section{Docking analysis}

In silico docking study was performed to perceive the inhibiting potential of selected plant-derived compounds against alpha-amylase and alpha-glucosidase enzyme. The docking studies were performed by the use of AutoDock 4.2. The binding electricity for each selected compound with the alpha-amylase (1SMD) and alpha-glucosidase (3wy1) enzymes using AutoDock 4.2 is given in desk 1 and 2. Docking research displays that the ligands bind to the active website online region of alpha-amylase (1SMD) and alpha-glucosidase (3wy1) 


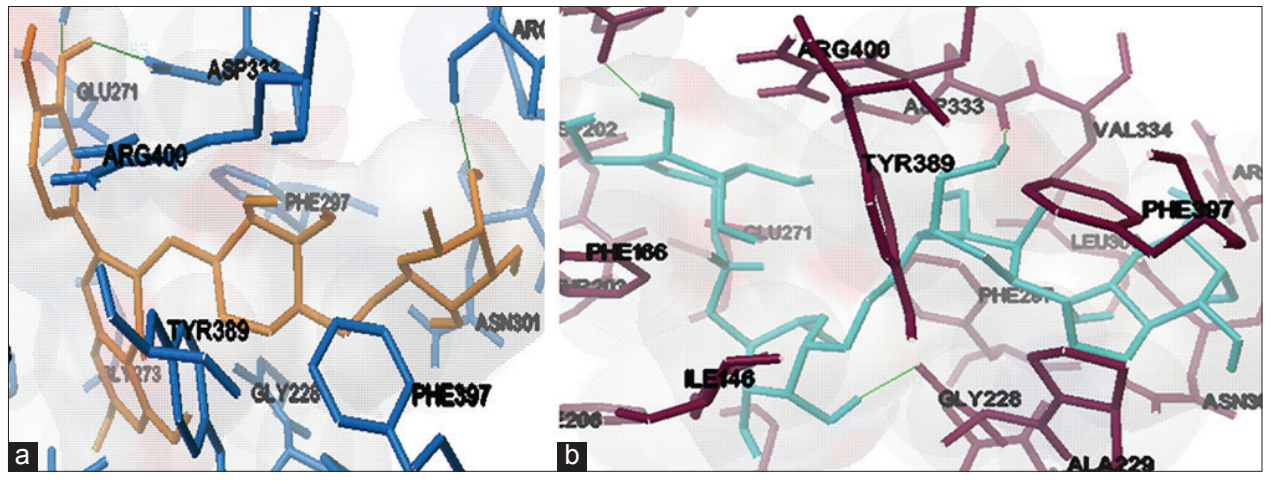

Fig. 3: (a and b) Docked pose of alpha-glucosidase (3WY1) with rutin and standard acarbose

Table 1: ${ }^{13} \mathrm{C}$ nuclear magnetic resonance interpretation value of isolated compound from Amaranthus tristis Linn. with reference rutin

\begin{tabular}{lllll}
\hline S. No & Isolated compound & Reference rutin & Compound-I (isolated rutin) & Reference rutin \\
\hline 1 & $144.72(\mathrm{C} 2)$ & 144.8 & $116.26\left(\mathrm{C} 6^{1}\right)$ & 116.36. \\
2 & $133.31(\mathrm{C} 3)$ & 133.41 & $101.20\left(\mathrm{C}^{11}\right)$ & 101.32 \\
3 & $177.35(\mathrm{C} 4)$ & 177.48 & $74.07\left(\mathrm{C}^{11}\right)$ & 74.18 \\
4 & $161.20(\mathrm{C} 5)$ & 161.33 & $76.47\left(\mathrm{C}^{11}\right)$ & 76.57 \\
5 & $98.65(\mathrm{C} 6)$ & 98.53 & $68.19\left(\mathrm{C}^{11}\right)$ & 68.33 \\
6 & $156.56(\mathrm{C} 7)$ & 156.73 & $75.91\left(\mathrm{C} 5^{11}\right)$ & 76.01 \\
7 & $93.55(\mathrm{C} 8)$ & 93.69 & $66.97\left(\mathrm{C}^{11}\right)$ & 67.09 \\
8 & $100.70(\mathrm{C} 9)$ & 100.84 & $101.20\left(\mathrm{C}^{111}\right)$ & 701.0 \\
9 & $156.40(\mathrm{C} 10)$ & 156.55 & $70.57\left(\mathrm{C}^{111}\right)$ & 70.52 \\
10 & $121.56\left(\mathrm{C} 1^{1}\right)$, & 121.70 & $70.01\left(\mathrm{C} 3^{111}\right)$ & 70.48 \\
11 & $116.26\left(\mathrm{C} 2^{11}\right)$ & 116.70 & $68.19\left(\mathrm{C} 6^{111}\right)$ & 17.55 \\
12 & $144.72\left(\mathrm{C} 3^{1}\right)$ & 144.84 & $17.67 \mathrm{C}-\mathrm{CH} 3$. & \\
13 & $148.38\left(\mathrm{C} 4^{1}\right)$ & 148.5 & & \\
\hline
\end{tabular}

Table 2: The interaction energies (kcal/mol) of 1SMD with rutin and acarbose

\begin{tabular}{lllll}
\hline S. No & Lead compound & Binding energy (Kcal/mol) & Inhibitory constant $(\boldsymbol{\mu M})$ & Hydrogens \\
\hline 1 & Rutin & -6.77 & 11.66 & 2 \\
2 & Standard (acarbose) & -2.94 & 6.98 & 3 \\
\hline
\end{tabular}

Table 3: The interaction energies (kcal/mol) of 3WY1 with rutin and acarbose

\begin{tabular}{lllll}
\hline S. No & Lead compound & Binding energy $(\mathrm{Kcal} / \mathbf{m o l})$ & Inhibitory constant $(\boldsymbol{\mu M})$ & Hydrogens \\
\hline 1 & Rutin & -10.53 & 18.99 & 3 \\
2 & Standard (acarbose) & -2.65 & 11.32 & 3 \\
\hline
\end{tabular}

enzymes with top binding power compared to standard. The docking fashions of the compounds and well known in three-dimensional view are proven in Figs. 2 and 3.

As shown in Tables 1-3, rutin showed binding energy ranging between $-6.77 \mathrm{kcal} / \mathrm{mol}$. The rutin had showed binding energy compared to that of standard acarbose $(-2.94 \mathrm{kcal} / \mathrm{mol})$. This proves that rutin consists of potential diabetic inhibitory binding sites more to that of the standard.

As shown rutin showed binding energy ranging between $-10.53 \mathrm{kcal} / \mathrm{mol}$. The rutin had showed binding energy compared to that of standard acarbose $(-2.65 \mathrm{kcal} / \mathrm{mol})$. This proves that rutin consists of potential diabetic inhibitory binding sites more to that of the standard.

Compounds from A. tristis Linn. indicated better binding features with the alpha-amylase and alpha-glucosidase; these compounds can be viably utilized as new medication for treating diabetes which is anticipated based on docking scores. The bits of knowledge picked up in this work can be additionally utilized as a part of exploratory examinations for outlining hostile to diabetic medications with novel targets and mechanism of action

\section{CONCLUSION}

The compounds from A. tristis Linn. showed better binding features with the alpha-amylase and alpha-glycosidase. Thus, these compounds can be effectively used as drugs for treating diabetes which is predicted on the basis of docking scores. The insights gained in this work can be further used in experimental studies for designing antidiabetic drugs with novel targets and mechanism of action.

\section{REFERENCES}

1. Kameswararao B, Kesavulu MM, Apparao C. Evaluation of antidiabetic effect of Momordica cymbalaria fruit in alloxan-diabetic rats. Fitoterapia 2003;74:7-13

2. Mukherjee PK, Maiti K, Mukherjee K, Houghton PJ. Leads from Indian medicinal plants with hypoglycemic potentials. J Ethnopharm 2006;106:1-28.

3. Murugan SB, Reshma A, Deepika R, Balamurugan S, Sathishkumar R. Antioxidant capacities of Amaranthus tristis and Alternanthera sessilis: A comparative study. J Med Plants Res 2013;7:2230-5.

4. Sundarrajan T, Vjeyaanandhi V. Phytochemical evaluation and in vitro antidiabetic activity of ethanolic extract of Amaranthus tristis Linn. J Pharm Sci Res 2017;9:1586-7. 
5. Morris GM, Huey R, Lindstrom W, Sanner MF, Belew RK, Goodsell DS, et al. AutoDock4 and autoDockTools4: Automated docking with selective receptor flexibility. J Comput Chem 2009;30:2785-91.

6. Ganugapati J, Baldwa A, Lalani S. Molecular docking studies of banana flower flavonoids as insulin receptor tyrosine kinase activators as a cure for diabetes mellitus. Bioinformation 2012;8:216-20.

7. Sundarrajan T, Aanandhi VM. Hypolipidemic activity of Amaranthus tristis Linn in triton WR-1339 induced hyperlipidemic rats. Res J Pharm Technol 2017:10:171-81

8. Jaiswal JV, Wadegaonkar PA, Hajare SW. The bioflavonoid galangin suppresses the growth of Ehrlich ascites carcinoma in Swiss albino mice: A molecular insight. Appl Biochem Biotechnol 2012;167:1325-39.

9. Peng $X$, Zhang G, Liao Y, Gong D. Inhibitory kinetics and mechanism of kaempferol on $\alpha$-glucosidase. Food Chem 2016;90:207-15.

10. Rajan AP, Jayachandra S, Lulu S, Manju SL. In silico screening and molecular docking to identify a novel inhibitor for aldose reductase. J Pharm Sci Res 2017;9:1169-72.

11. Princy KR, Sripathi R, Dharani J, Ravi S. Molecular docking studies of alkaloids from Desmodium triflorum against bacterial proteins. J Pharm Sci Res 2017;9:1882-88 